\title{
STUDENTS' DIFFICULTIES IN SOLVING MATHEMATICAL PROBLEMS
}

\section{SAMSUL HADI ${ }^{1}$, TATANG HERMAN ${ }^{2} \&$ AAN HASANAH ${ }^{3}$}

${ }^{I}$ Master Program of Mathematics Education, Universitas Pendidikan Indonesia, Bandung, Indonesia

${ }^{2,3}$ Department of Mathematics Education, Universitas Pendidikan Indonesia, Bandung, Indonesia

The purpose of this study is to analyze the ability and students' difficulties in solving mathematical problems. This study is a qualitative research with the number of participants - 32 students consisting of 16 male students and 16 female students with an age range of 12-13 years. Data were collected by observation, interviews, and tests of social arithmetic problems. The results showed that junior high school students have low ability in solving mathematical problems. The low ability of students' mathematical problem solving is caused by several factors, namely (1) students can not understand the keyword of social arithmetic problem; (2) students can not develop problem solving strategy based on problem in question; (3) students easily give up in the face of every difficulty and error; (4) students do not like to read long and unclear questions in reading questions; (5) students are not careful in the calculation process; (6) the student is wrong in taking and determining the concept or strategy of completion; and (7) the students did not verify either in terms of concepts, strategies, calculations, and answers. In subsequent research, our objective is to focus more on student activities in solving mathematical problems.
\end{abstract}

KEYWORDS: Mathematical Problems, Problem Solving \& Social Arithmetic

Received: Jan 03, 2018; Accepted: Jan 24, 2018; Published: Feb 05, 2018; Paper Id.: IJESRFEB20188

\section{INTRODUCTION}

The meaningfulness of learning can help students in solving problems in everyday life. Basically every day, we are faced with a problem, even though not all of these problems are mathematical problems, but to solve the problem requires mathematical thinking. However, in the face of problems, everyone has different situations and views on the problems. That is, the same problem may not necessarily have the same way in finding the idea / strategy of the solution. In other words, a simple situation can be a complex issue for others, but on the other hand it may not be a problem. This is because everyone has the knowledge (prior knowledge) and experience differently in solving the problem. Problem solving is one of the mathematical competencies recommended in mathematics learning.

National Council of Teachers Mathematics (NCTM) (2000) suggests that there are several components of the ability of students in learning mathematics, namely (1) mathematical communication; (2) mathematical reasoning; (3) mathematical problem solving (mathematical problem solving); (4) mathematical connections; and (5) representation.

Student troubleshooting skills can develop, if teachers encourage students to learn according to the basic view of the 2013 curriculum that knowledge cannot be transferred from teacher to student. This means that students are given the opportunity to develop their potential, especially in terms of synthesizing problems and constructing knowledge in solving problems. The goal is that students really understand and apply knowledge, 
students need to be encouraged to solve problems, find everything for themselves, and strive to realize the ideas / ideas in solving the problem. As we all know that students are subjects who have the ability to search, process, construct, and use knowledge (Saefudin\&Berdiati, 2015).

The troubleshooting process is different from the process of solving the problem. The differences are in the context of problems and problems. Solving math problems is not necessarily categorized as solving a mathematical problem. If a mathematical problem is found immediately the solution, then the problem is categorized as a matter of routine and not a mathematical problem. However, the mathematical problem that requires a solution step and the problem is not immediately found the solution, then the mathematical problem is categorized as mathematical problems (Sumarmo, 2013). Similarly, Djamilah (2009) pointed out that a situation is a problem if the situation is challenging to be resolved or answered, and procedures to solve it. This is requiring various mathematical concepts and skills in making decisions (Tambychik\&Subahan, 2010).

Facts indicate that students have difficulties in solving non-routine mathematical problems, as Juwita (2017) suggests that low mathematical problem solving of students is closely related to the low mathematical understanding of students to math problems, lack of skill in finding various solutions, non routine math problems. Ramirez et al (2016) stated that the development of the problem solving ability of students is influenced by the cognitive aspect capacity of the students. That is, students who have less knowledge and do not have a high struggle in overcoming the difficulties / problems faced mathematics then indirectly indicates the ability of solving the problem of mathematical students low. In addition, the low ability of mathematical problem solving of students is caused by the lack of careful and skilled students to construct new knowledge and do not have prior knowledge or sufficient knowledge schemata so that students are often wrong in preparing a settlement strategy. Difficulties in solving problems would lead to errors in finding solutions so that the effort required of students in overcoming the difficulty (Granberg, 2016).

From the description of the above problems, the authors are encouraged to conduct a study that focuses on the ability of junior high students in solving social arithmetic problems. Social arithmetic is one of the interesting math studies studied because the problems associated with social arithmetic often occur in everyday life. This means that combinatoric problems are consistent with the principles of problem solving ie problems presented in contextual form. In addition, social arithmetic is one of the interesting material to be studied because the presentation of the problem of social arithmetic is usually in the form of story problems so that researchers can find out how far the ability and difficulty of students in solving social arithmetic problems. This is because students experience many difficulties when solving math problems in the form of stories (Ahmad, Tarmizi, \&Nawawi, 2010). Therefore, this study will try to analyze the ability of junior high school students in solving math problems. Analysis of the ability of junior high students in solving mathematical problems is done by qualitative analysis. Some reasons for qualitative analysis are: (1) to examine the process / activity of the students in depth during the learning process in solving mathematical problems related to mathematical skills that not only look at the learning product but also the process; (2) qualitative study in mathematics learning is rarely done in the learning that can in developing the critical, creative, and innovative thinking of the researcher and (3) overcome the problem of this study more precisely done with qualitative approach. This is because the data obtained by researchers more complete, deep, meaningful, and credible. Thus, the title in this study, "Analysis of Junior Student Ability in Solving Mathematical Problems". Based on the above description, the focus of the problem studied in this research is to know the description of the ability and difficulty of junior high school students in solving mathematical problems. 


\section{THEORY REVIEW}

\section{Mathematical Problems}

A problem / question is not directly a problem. Questions will be a problem, if the question indicates a challenge that can not be resolved immediately from the routine procedures the students already know. Newell \& Simon pointed out that the problem is a situation where one wants to do something but does not know how / strategy is done in getting a desired goal (Darminto, 2010). Bell (1978) says that the situation is said to be a problem for a person if he is aware of a problem in that situation, knowing that the problem must be solved, challenged to do something about it, but not immediately solved.

Hudojo (1988) says that in mathematics a problem or question would be a problem if there is no specific rule or law that can be used immediately to find the answer. Saad\&Ghani (2008) says that mathematical problems are situations that have clear goals but at the same time are faced with an obstacle caused by a lack of known algorithms in finding solutions. Polya (1973) says that the problem of mathematics there are two types, namely (1) the problem of finding (problem to find), a problem that aims to find, determine, or obtain the value of an object that is not stated in the question; and (2) problem to prove (problem to prove), a problem that requires a procedure in showing a true statement or not.

Ruseffendi (2006) says that there are three criteria a problem is said to be a mathematical problem, namely (1) the problem is not yet known how to solve; (2) mathematical problems in accordance with the prior knowledge of students; and (3) students have a desire to solve the problem Fung \& Roland (2004) says that there are several characteristics of a mathematical problem, namely: (1) math problems should contain more than one settlement step; (2) math problems should contain more than one method of settlement; (3) math problems should use clear and understandable language or sentence to avoid misinterpretation; and (4) math problems should contain real mathematical concepts so as to enhance students' understanding and knowledge of mathematics. Based on the above opinion, it can be concluded that the problem of mathematics is a situation that is not immediately found a solution caused by lack of completion algorithm needed in finding and determining the desired goal.

\section{Troubleshooting Mathematics}

Polya (1973) says that problem solving is seen as an attempt to find a way out of difficulties or problems. Saad\&Ghani (2008) said that problem solving is a process that requires planning in performing an action that aims to find the desired solution of a problem whose solution is not immediately found. Turmudi (2009) says that problem solving is a process involving a task whose method of solution is not known first.

Sumarmo (2005) says that problem solving has two meanings: (1) problem solving is seen as a learning approach, used in reinvention of material understanding, concepts, mathematical principles and problem solving. Learning begins by presenting a contextual problem then through student induction to discover the mathematical concepts / principles; and (2) problem solving is seen as a hard skill that has indicators, including: identifying the adequacy of data in solving a problem, creating mathematical models and solving them, selecting and implementing strategies in solving mathematical problems and / or outside mathematics, and explaining or interpreting the results of solutions problem and re-examine the answers obtained.

In solving the problem of one's willingness to engage in a problem is needed in achieving the goal. In addition, a person can develop himself into a constructive and reflective person in the face of problems. This is due to the condition of 
one's ability to engage in the cognitive thinking process to understand and overcome the problem (Csapó\&Funke, 2017). So is the case with students, students as individuals and social groups both at school and in society are often faced with a problem in everyday life. The problem may be simple and complex.

The ability of students to overcome these problems can be grown by teachers through learning mathematics by developing aspects of problem solving of students' mathematics, is (1) build mathematical knowledge through problem solving; (2) applying and adapting various appropriate strategies to solve the problem; (3) observing and developing the process of solving mathematical problems; and (4) solving mathematical problems that arise in other contexts (NCTM, 2000).

From the above opinion, it can be concluded that problem solving is an activity to find a way out of the problems faced by students in learning by applying knowledge both mathematical concepts / principles, strategies, and experience. In solving a mathematical problem required a technique or strategy. Problem solving technique is very needed students in solving a problem in everyday life. Here are some basic heuristics (generic) in mathematics (Sickafus, 2004), namely: (1) find a pattern; (2)draw; (3) formulate an equivalent problem; (4) modify the problem; (5)choose effective notation;(6)using symmetry problems; (7) divide into cases; (8)work backward; (9) argue by contradiction; (10)check for similar problems; (11)identify extreme cases; (12) generalize.

\section{Troubleshooting Activities}

In solving the problem there are several activities that students do in obtaining a solution of the problem / problem. Schoenfeld (Granberg, 2016) says that there are five stages of problem solving activities that students can do, namely (1) reading the problem, this stage students record key words, ask other students what is asked in the problem, or to relate the problem to a more understandable language or sentence; (2) analyzing the problem, this stage analyzes the problem by identifying what problems are known and asked; (3) exploration, this stage students make the process of formation of new concepts / knowledge based on knowledge or schemata and existing experience, and check whether the previous knowledge is in accordance with the problem; (4) plan, the process undertaken at this stage is the students build or construct the requested solution based on the previous stage; and (5) verifying solution method, this stage students take action based on the plan or strategy that has been determined by student in problem solving. After that the student verifies the answer or process that has been done by checking again whether the answer and the process done is in accordance with the question of the problem.

Polya (1973) says that there are four stages of activity done on problem solving, namely (1) understand the problem, this stage required students' understanding of a problem encountered by identifying what is known, what is asked, the existing elements, the number, the relationships, and the associated values and what they are looking for. There are several recommendations that can help students understand a problem, namely (a) to ask what is known and sought; (b) explain the problem by its own sentence; (c) connecting with similar problems; (d) focus on the importance of a problem; (e) modeling; and (f) create diagrams; (2) plan a devise (a) plan, this stage students identify which operations and strategies are involved in solving the problem. There are several steps students can take in this stage, namely (a) guessing; (b) developing the model; (c) sketch diagrams; (d) simplify the problem; (e) identifying patterns; (f) create tables (g) experiments and simulations; (h) working inversely; (i) testing all possibilities; (j) identifying sub-goals; (k) make an analogy; and (1) sorting data / information; (3) carry out the plan, this stage what is done on an action is based on the plan that has been designed. This can be done with several things, namely (a) interpreting information into mathematical form; 
and (b) perform a strategy during the process and calculation. Basically, this stage students are required to perform an action based on a predetermined plan, but if not running students can use other plans that can help students solve problems; and (4) looking back, this stage there are several things students need to take into account in reviewing the process that has been done during the troubleshooting, namely (a) re-examining all the information that has been identified; (b) recheck all calculations made; (c) consider whether the solution is found logical; and (d) review possible alternative solutions and ask yourself if the question has really been answered.

Krulik\&Rudnik said that there are five stages of activity done in solving the problem, namely (1) reading, this stage the students record key word, ask other students what is asked in the problem, return the problem to a more understandable language or sentence; (2) explore, this stage students looking for patterns based on information that is collected in determining the concept or principles of mathematics required. In addition, students identify problems, presenting the problem into easy-to-understand sentences. Questions that can be used in this exploration stage, 'what is the problem' like? at this stage students also can usually create tables; (3) select a strategy, this stage of the process that students do is make a conclusion or hypothesis about how to solve the problem based on what has been read and explored; (4) solve the problem, this stage requires all the students math skills in solving problems; and (5) review and extend (review and extend), this stage of the students re-examine the solutions that have been obtained and the process / way of calculation that has been done(Carson, 2007).

\section{Troubleshooting Difficulty Mathematics}

Difficulties of students in learning mathematics, especially in solving the problem of mathematics basically ditengarahi by abstract mathematics study. Soedjadi (2000) says that mathematics has characteristics, namely (1) the study is abstract; (2) more relies on the agreement; (3) deductive mindset; (4) consists of symbols; (5) rests more on the universe of speech; and (6) consistent in the system. The difficulties of students in solving mathematical problems are closely related to students' inability to answer a teacher's problem, where the problem is viewed as a form of personal obstacle and pressure rather than a valuable learning (Bell, 1978). Difficulties experienced by students resulted in difficulties in students' understanding, oral and written usage, thinking, speaking, reading, writing, and mathematical operations (OECD, 2009).

Cooney, Davis, \& Henderson (1975) said that students' difficulties in mathematics are grouped based on two types of knowledge, namely knowledge of concepts and knowledge of principles. Then students' difficulties in math problem solving are extended when students solve verbal math problems, namely difficulty on concepts, difficulty on principles, and difficulty on verbal settlement. Bell (1978) said that students 'difficulties in solving mathematical problems are caused by students' difficulties in reading to understand a problem from the problem at hand.

Phonapichat, Wongwanich, \& Sujiva (2014) said that some of the students' difficulties in solving problems, namely (1) students have difficulty in understanding the keywords that appear in the problem so that students can not interpret into the mathematical model; (2) students can not know what assumptions and information students need in solving problems; (3) every student can not understand the problem, students tend to guess the answer without thinking process; (4) students are impatient and do not like to read about; and (5) students do not like to read long questions. Based on the above opinion, it can be concluded that the difficulty of solving mathematical problems is a form of barriers experienced by students in solving mathematical problems both related to concepts, principles, and verbal. Geary \& Garnet (Tambychik \& Subahan, 2010) say that the lack of math skills in students will cause difficulties in problem solving. 
Phonapichat, Wongwanich, \& Sujiva (2014) said that the skills students must have in solving problems, namely: reading skills, computing, and mathematical skills. Of these three skills, reading skills are a major factor in problem solving. Through reading ability students can understand the context of the problem to be solved.

\section{METHODS}

This research is done by using qualitative research method. In this study the collected data is not only in the form of numbers, but the data are collected from interviews, observations, field notes, and other official documents. This means that the data obtained in the study is descriptive-shaped data, in the form of writing from research subjects. Arifin (2012) said that qualitative research is a research process that dilakuan naturally and naturally in accordance with the objective conditions in the field without any data manipulation. Strauss \& Corbin says that qualitative research can be used in obtaining complicated data / information about a phenomenon such as feelings, thought processes, and emotions that are difficult to learn through conventional methods (Creswell, 2015). The type of qualitative research used in this research is a case study, Rahardjo (2017) said that case study is a series of scientific activities conducted intensively, in detail and in depth about a program, event, and activity, either individual or group, institution or organization in obtaining an in-depth knowledge of the event.

This research was conducted in one of the State Junior High Schools in Bandung. Based on the title of the research taken by the author, "Analysis of Ability of Junior Students in Solving Mathematical Problems" then the participants of this study are 7th grade junior high school consisting of 16 male students and 16 female students with an age range of 12-13 years in the school year 2017/2018. The selection of research participants is based on certain considerations. As the technique of taking participants in this study is purposive sampling. Purposive sampling is a technique of sampling the data source based on certain considerations (Sugiyono, 2011). The main instrument in this study is the researchers themselves, this is due to the direct involvement of researchers with research participants in understanding the events in the field either through observation, interviews, and documentation studies (Moleong, 2010).

\section{RESULTS AND DISCUSSIONS}

Factual information in the research can be seen from the workmanship of the mathematical problem-solving test given by the researcher in measuring the ability and the fighting power of students in solving social arithmetic problem. The example of problem and result of solving one of the participants in solving the problem solving of social arithmetic in this research can be seen in Figure 1.1 below:

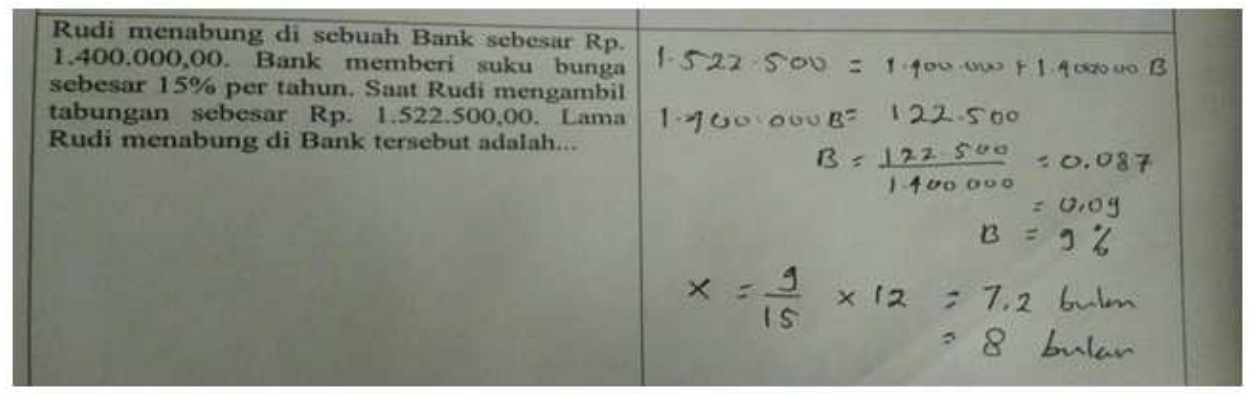

Figure 1 Student's Answer in Determining Saving Time

Based on Figure 1, the description of students' social arithmetic problem solving ability is still low. It is shown that the student is unable to solve the problem based on the problem solving indicator. For example, students are unable to 
mention and write down what data is known and what data is being asked, students can not understand the problem correctly, wrong in preparing and implementing a settlement strategy that has a wrong result in the calculation process, and the student does not verify the strategy, and answers.

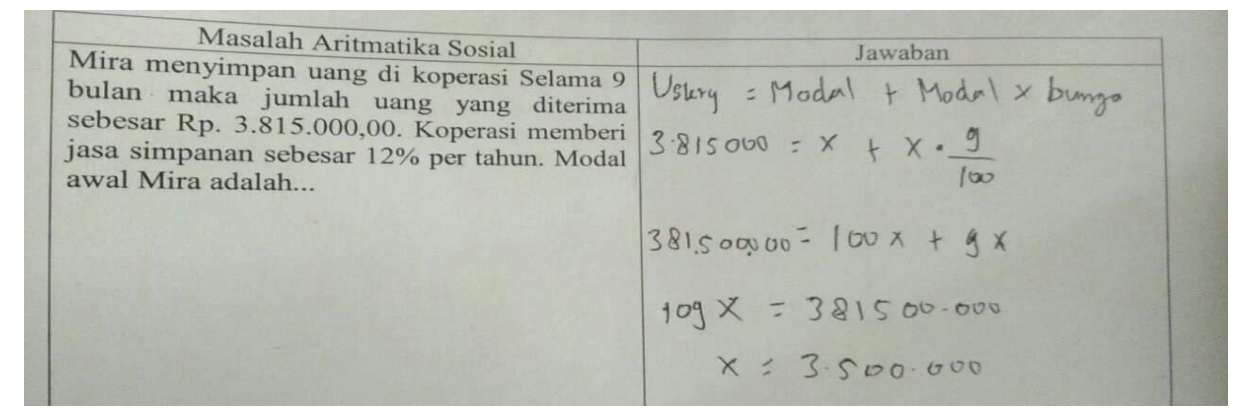

Figure 2: Student's Answer in Determining Initial Capital

From Figure 2 can be obtained information that one of the participants in this study showed that students have low problem solving ability. In the picture, students are able to solve social arithmetic problems correctly from both the answers and the calculation process. However, the students were unable to name the known and asked data and the students did not verify the process and the answers mainly related to the problem solving strategy. The low problem solving of students 'mathematics is closely related to students' mathematical understanding of mathematical problems, lack of skill in finding various ways of completion, and students have less practice solving non routine math problems. Cooney, Davis, \& Henderson (1975) said that students' difficulties in mathematics are grouped based on two types of knowledge, namely knowledge of concepts and knowledge of principles. Then students' difficulties in solving mathematical problems are expanded when students solve verbal math problems, namely difficulty on concepts, difficulty on principles, and difficulty on verbal settlement.

Difficulties of students in solving mathematical problems caused by students' difficulties in reading to understand a problem of problems faced. This can be known when students are asked to read the problem aloud and interpret it per sentence (Bell, 1978). Based on the results of interviews with the participants it can be concluded that students' difficulties in solving social arithmetic problems, namely (1) students have difficulty in understanding the keywords that appear in the problem so that students can not interpret into the mathematical model; (2) students can not know what assumptions and information students need in solving problems; (3) every student cannot understand the problem, students tend to give up easily and guess the answer without thinking process; (4) students are impatient and do not like to read about the problem; and (5) students do not like to read long problems. This means that students have low motivation or motivation in facing any difficulties in solving social arithmetic problems.

\section{CONCLUSIONS}

Problem solving is one of the mathematical competencies that must be developed in the learning of mathematics. Through problem solving competencies, students are expected to solve both simple mathematical problems and complex problems in everyday life. However, the factual conditions illustrate that the ability of junior high students in solving mathematical problems is still relatively low, especially the problem of social arithmetic. Several factors influence the low ability of students' mathematical problem solving, ie (1) students can not understand the keyword of social arithmetic problem; (2) students can not develop problem solving strategy based on problem in question; (3) students easily give up in the face of every difficulty and error; (4) students do not like to read long and unclear questions in reading questions; (5) 
students are not careful in the calculation process; (6) the student is wrong in taking and determining the concept or strategy of completion; and (7) the students did not verify either in terms of concepts, strategies, calculations, and answers. In subsequent research to focus more on student activities in solving mathematical problems.

\section{REFERENCES}

1. Ahmad, A., Tarmizi, A.R., \& Nawawi, M. (2010). Visual Representations in Mathematical Word Problem Solving Among Form Four Students in Malacca. Procedia Social Behavioral Sciences 8, 356-361.

2. Arifin, Z. (2012). Penelitian Pendidikan (Metode dan Paradigma Baru). Bandung: PT Remaja Rosdakarya.

3. Bell, Frederick H. (1978). Teaching and Learning Mathematics: In Secondary Schools. Second Printing. Dubuque, lowa: Wm. C. Brown. Company.

4. Carson, J. (2007). A Problem with Problem Solving: Teaching Thinking without Teaching Knowledge. The Mathematics Educator Journal, 17(2), 7-14.

5. Cooney,T, J., Davis, J, E., \& Henderson, B, K. (1975). Dynamics of Teaching Secondary School Mathematics. Boston, MA:Hougthon Mifflin Company.

6. Creswell, J. (2015). Riset Pendidikan: Perencanaan, Pelaksanaan, dan Evaluasiriset Kualitatif dan Kuantitatif. Yogyakarta: Pustaka Pelajar.

7. Csapó, B. and J. Funke. (2017). The Nature of Problem Solving: Using Research to Inspire 21st Century Learning. Paris: OECD Publishing.

8. Darminto. B.P. (2010). Peningkatan Kreativitas dan Pemecahan Masalah Bagi Calon Guru Matematika Melalui Model Pembelajaran Trefinger. Makalah Dipresentasikan pada Seminar Nasional Matematika dan Pendidikan Matematika. Yogyakarta, 27 November 2010.

9. Helen Shaji John Cecily \& Akram Omoush, Efficacy of Problem Based Learning (PBI) Over Lecture Method in Enhancing the Critical Thinking Skills and Problem Solving Ability Among Nursing Students in KSA, International Journal of Educational Science and Research (IJESR), Volume 4, Issue 5, September - October 2014, pp. 1-8

10. Depdiknas. 2016. Silabus Mata Pelajaran Sekolah Menengah Pertama/Madrasah Tsanawiyah (SMP/MTs). Jakarta.

11. Djamilah B, W. (2009). Kemampuan Pemecahan Masalah Matematika Mahasiswa Calon Guru Matematika: Apa dan Bagaimana Mengembangkannya. Seminar Nasional Matematika dan Pendidikan Matematika 2009. Prosiding: ISSN 978-979-16353-3-2.

12. Fung, M.G., \& Roland, L. (2004). Writing, Reading, and Assessing in An Elementary Problem Solving Class. In Problems, Resources, and Issues in Mathematics Undergraduate Studies. Desember 2004. Proquest Educatio Journals.

13. Granberg, C. 2016. Discovering and Addressing Errors During Mathematics Problem-Solving-A Productive Struggle? The Journal of Mathematical Behavior 42, 33-48.

14. Sumanlata Saxena, Rajat Kumar Jain \& Hement Kumar Jain, Impact of Cognitive Style on Problem Solving Ability among Undergraduates, International Journal of Human Resource Management and Research (IJHRMR), Volume 4, Issue 2, March April 2014, pp. 59-64

15. Herman, T. (2000). Strategi Pemecahan Masalah (Problem-Solving) dalam Pembelajaran Matematika. Makalah Disajikan dalam Kegiatan Asistensi Guru Madrasah Ibtidaiyah dan Tsanawiyah Jawa Barat Tanggal 28 September s.d. 3 Oktober 2000.

16. Hudojo, H. (1988). Mengajar Belajar Matematika. Jakarta: P2LPTK, Dirjen Dikti, Depdikbud. 
17. Juwita, H. (2017). Peningkatan Kemampuan Pemecahan Masalah Matematika dan Self Efficacy Siswa MTS Melalui Model Pembelajaran Pogil. Tesis. UPI. Tdak diterbitkan.

18. Moleong, L. (2010). Metodelogi Penelitian Kualitatif(Edisi Revisi). Bandung: Remaja Rosdakarya.

19. NCTM. (2000). Principles and Standards for School Mathematics. Reston, VA: Author.

20. OECD. (2009). Students with Disabilities, Learning Difficulties and Disadventages in The Balitic States, South Eastern Europe and Malta. London, UK: European Commission-Joint Research Centre (JRC).

21. Phonapichat, P., Wongwanich, S., \& Sujiva, S. (2014). An Analysis of Elementary School Students' Difficulties in Mathematical Problem Solving. Procedia- Social and Behavioral Sciences 116, 3169-3174.

22. Polya, G. (1973). How to solve It. New Jersey: Princeton University Press.

23. Rahardjo, M. (2017). Studi Kasus Dalam Penelitian Kualitatif; Konsep dan Prosedurnya. UIN Maulana Malik Ibrahim, Malang.

24. Ramirez, G et al. (2016). On The Relationship between Math Anxiety and Math Achievment in Early Elementary School: The Role of Problem Solving Strategis. Journal of Experimental Child Psychology 141, 83-100.

25. Ruseffendi. (2006). Pengantar Epada Memebantu Guru Mengembangkan Kompetensinya Dalam Pengajaran Matematika untuk Meningkatan CBSA. Bandung: Tarsito.

26. Saad, N.S \& Ghani, A. S. (2008). Teaching Mathematics in Secondary School: Theories and Practises. Perak: Universiti Pendidikan Sultan Idris.

27. Saefudin, A \& Berdiati, I. (2015). Pembelajaran Efektif. Bandung: PT Remaja Rosdakarya.

28. Sickafus, Ed.(2004). Heuristics for Solving Technical Problem : Theory, Derivation, Application. Grosse lle : Ntelleck LLC.

29. Soedjadi. (2000). Kiat Pendidikan Matematika di Indonesia. Jakarta: Dikti.

30. Sugioyono. (2011). Metode Penelitian Kuantitaif, Kualitatif dan R\&D. Bandung: Alfabeta.

31. Sumarmo, U. (2005). Pembelajaran Matematika untuk Mendukung Pelaksanaan Kurikulum Tahun 2002 Sekolah Menengah. Makalah pada Seminar Pendidikan Matematika di FMIPA Universitas Negeri Gorontalo.

32. Tambychik, $T$ \& Subahan, T. (2010). Students' Difficulties in Mathematics Problem Solving: What Do They Say? Procedia Sosial and Behavior Science 8, 142-151.

33. Turmudi. (2009). Pemecahan Masalah Matematika. Materi Disampaikan Dalam Rangka Pengembangan Pendidikan Guru Madrasah Ibtidaiyah di IAIN Arraniri. Banda Aceh, 27-29 Juli 2009. 
